\title{
Opsonophagocytosis of Campylobacter pylori
}

\author{
S. S. DAS*, Q. N. KARIM and C.S. F. EASMON
}

\begin{abstract}
Department of Medical Microbiology, Wright-Fleming Institute, St Mary's Hospital Medical School, Praed Street, London W2 1PG
\end{abstract}

\begin{abstract}
Summary. The opsonic activity of human serum from various sources against Campylobacter pylori was compared. All sera, whether from control subjects with no symptoms of gastritis or peptic ulceration, or from symptomatic patients from whom $C$. pylori had or had not been isolated, opsonised C.pylori equally well. Opsonisation depended on the alternative pathway of complement activation but not on antibody. These findings suggest that antibody plays no role in protection against $C$. pylori and that the presence of antibody in patients' sera is mainly of diagnostic value.
\end{abstract}

\section{Introduction}

Campylobacter pylori, a spiral micro-aerophilic organism, was first detected in cultures of gastric antral mucosal biopsy specimens by Marshall in 1983. Since then many studies have demonstrated a strong correlation between the presence of $C$. pylori and histologically proven gastritis and peptic ulcer (McNulty and Watson, 1984; Price et al., 1985). The aetiological significance of this organism in these diseases remains doubtful. $C$. pylori has been shown to provoke both a systemic and a local immune response (Jones et al., 1984; Kalder et al., 1985; Rathbone et al., 1986; Wyatt et al., 1986). The demonstration of $C$. pylori-specific $\mathrm{IgG}$ in serum and $\operatorname{IgA}$ in gastric juice have been taken to provide further evidence of a pathogenic role for the organism in gastro-duodenal disease. The aim of our study was to investigate whether the serum antibodies induced by $C$. pylori have opsonic activity for the organism and, accordingly whether they are likely to be protective.

\section{Materials and methods}

\section{Patients and sera}

One serum sample obtained from each of 35 patients undergoing investigation for upper abdominal symptoms was tested separately in all the experiments; the test sera were not pooled. $C$. pylori was isolated from mucosal biopsy specimens taken from the gastric antrum, duodenum, and oesophagus of 20 patients. Single serum

Received 20 Aug. 1987; revised version accepted 15 Mar. 1988. *Present address and address for correspondence: Public Health Laboratory, Dulwich Hospital, East Dulwich Grove, London SE22 8QF. samples from 15 healthy individuals were taken and pooled to act as a control. Serum samples were heated at $56^{\circ} \mathrm{C}$ for $30 \mathrm{~min}$ to destroy complement. The classical complement activation pathway was inhibited selectively by treating with a solution containing $100 \mathrm{mM} \mathrm{MgCl}$ and $100 \mathrm{mM}$ ethylene glycol tetraacetate (MgEGTA; Sigma). Serum was also obtained from a patient with agammaglobulinaemia and used as a source of antibodyfree complement. Serum devoid of antibodies to $C$. pylori was produced by absorption of serum three times at $4^{\circ} \mathrm{C}$ for 45 min with $10^{10}$ washed and packed $C$. pylori cells.

\section{Preparation of micro-organisms}

C. pylori was grown on $7 \%$ horse-blood agar incubated at $37^{\circ} \mathrm{C}$ in a micro-aerophilic atmosphere provided by CampyPak $\mathrm{H}_{2}-\mathrm{CO}_{2}$ generator envelopes (BBL Microbiology Systems) in GasPak jars (BBL) with no catalyst. A suspension of the organism was made in saline $0.9 \% \mathrm{w} / \mathrm{v}$, centrifuged at $3000 \mathrm{~g}$ for $5 \mathrm{~min}$ and washed twice in saline. The organisms were then resuspended in Hanks's Balanced Salts Solution without phenol red (HBSS; Gibco) to give an optical density at $540 \mathrm{~nm}\left(\mathrm{OD}_{540}\right)$ of 0.5 , corresponding to a concentration of $1 \times 10^{9} \mathrm{cfu} / \mathrm{ml}$.

\section{Preparation of human peripheral blood leucocytes}

The same healthy human volunteer provided blood for preparation of leucocytes as and when required. Blood was taken by venepuncture and then heparinised with preservative-free heparin $(10 \mathrm{u} / \mathrm{ml})$. The erythrocytes were sedimented by gravity for $45 \mathrm{~min}$ at room temperature in dextran $6 \% \mathrm{w} / \mathrm{v}$ in saline $0.9 \% \mathrm{w} / \mathrm{v}$. The leucocyterich buffy layer was centrifuged at $350 \mathrm{~g}$ for $5 \mathrm{~min}$ and the supernate discarded. The residual red cells were lysed by treatment with $\mathrm{NH}_{4} \mathrm{Cl} 0.83 \% \mathrm{w} / \mathrm{v}$ in Tris- $\mathrm{HCl}$ buffer at pH 7.65 for $10 \mathrm{~min}$. The cells were washed twice and a total and differential white cell count obtained. The cells were then resuspended in HBSS supplemented with fetal 
calf serum (Tissue Culture Services, Slough, Berks) $1 \% \mathrm{v} / \mathrm{v}$ to give a concentration of $1.5 \times 10^{6}$ polymorphonuclear leucocytes (PMN)/ml, accounting for $70 \%$ of the total number of leucocytes present in the final suspension.

\section{Opsonisation}

Each of the serum samples from the 20 C. pylori culturepositive and 15 culture-negative patients and the pooled normal human serum was duplicated and entered separately into the experiment.

In 2-ml plastic vials, $0.5 \mathrm{ml}$ of bacterial suspension was added to $0.4 \mathrm{ml}$ of HBSS and $0.1 \mathrm{ml}$ of serum or other source of opsonin, to give a final opsonin concentration of $10 \% \mathrm{v} / \mathrm{v}$. The mixture was incubated for $15 \mathrm{~min}$ at $37^{\circ} \mathrm{C}$, centrifuged at $3000 \mathrm{~g}$ for $5 \mathrm{~min}$ and washed twice in phosphate buffered saline, $\mathrm{pH} 7 \cdot 2$ (PBS). The opsonised particles were then resuspended in $0.5 \mathrm{ml}$ of HBSS and kept at $4^{\circ} \mathrm{C}$ until ready to be used.

Opsonophagocytosis was studied by three methods that were essentially complementary to each other: luminol-dependent chemiluminescence; microscopical phagocytic assay; and indirect immunofluorescence. The first two are functional assays of opsonophagocytosis, measuring the uptake of bacteria by phagocytic cells. The IF test demonstrated the binding of opsonins to the surface of C. pylori.

Light emission in luminol-dependent chemiluminescence results from myeloperoxidase-dependent oxidation of luminol (Stevens et al., 1978). The source of myeloperoxidase is the azurophilic granules of PMN, eosinophils and monocytes. The number of PMN present in a peripheral blood leucocyte preparation far exceeds that of eosinophils and monocytes. Accordingly, the phagocytic activity of PMN accounts for most of the light emission in luminol-dependent chemiluminescence.

\section{Measurement of chemiluminescence}

A stock solution of luminol was made by dissolving $1.77 \mathrm{mg}$ of luminol (Sigma) in $1 \mathrm{ml}$ of dimethyl sulphoxide (DMSO; Sigma) to give a concentration of $10^{-2} \mathrm{M}$. This was diluted further in HBSS to the required concentration before use. Suspensions of opsonised bacteria $(0.2 \mathrm{ml})$ were added to $0.5 \mathrm{ml}$ of leucocyte suspension and $0.9 \mathrm{ml}$ of $10^{-5} \mathrm{M}$ luminol. The mixture was placed in the reaction chamber of a 1250 luminometer (LKB Co) for $15 \mathrm{~min}$ and the light generated was recorded in $\mathrm{mV}$.

\section{Microscopical phagocyctic assay}

Opsonised bacteria were diluted 100-fold in HBSS, and $0.2 \mathrm{ml}$ of this suspension was incubated with an equal volume of leucocyte suspension at $37^{\circ} \mathrm{C}$ for $15 \mathrm{~min}$, the tube being placed on a roller to ensure thorough mixing. Smears were prepared in a Cytospin centrifuge (Shandon Co.), fixed with methanol, stained with acridine orange $(10 \mathrm{mg} / \mathrm{ml}$ in distilled water), and examined under the oil immersion objective of a fluorescence microscope. Re- sults were expressed as the percentage of PMN with ingested C.pylori.

\section{Immunofluorescence}

A suspension of whole formalised $C$. pylori cells was prepared by adding five drops of a $40 \%$ formaldehyde solution to $20 \mathrm{ml}$ of bacterial suspension. The mixture was left at room temperature for $30 \mathrm{~min}$ and then centrifuged at $3000 \mathrm{~g}$ for $5 \mathrm{~min}$, and washed twice in saline. The cells were finally resuspended in HBSS to give an $\mathrm{OD}_{540}$ of $0 \cdot 2$.

To each well of a PTFE-coated slide (Hendley Ltd, Loughton, Essex) $0.02 \mathrm{ml}$ of formalised C. pylori suspension was applied. After drying in air and fixing in $70 \%$ alcohol, $\mathbf{0 . 0 2} \mathrm{ml}$ of serum or other source of opsonin was added to each well except the last two cells which contained $0.02 \mathrm{ml}$ of HBSS instead and acted as negative controls. The slide was placed in a moist chamber for 30 min at room temperature and then washed twice in PBS to remove any excess or unattached opsonin. To each well on the top row on the slide, $0.02 \mathrm{ml}$ of fluorescein isothiocyanate (FITC)-labelled rabbit anti-human IgG serum (Dako Ltd, High Wycombe, Bucks), diluted 10fold in PBS, was added. Similarly, FITC-labelled anti $\mathrm{C}_{3}$ serum was added to each well on the bottom row. The slide was then left in the moist chamber for $30 \mathrm{~min}$, washed twice in PBS, air-dried and examined with the oil immersion objective of a fluorescence microscope. The observed fluorescence was scored on an arbitrary scale of,,,-+-+++ , and +++ , representing the degrees of observed fluorescence as nil, weak, moderate, strong, and very strong respectively.

\section{Results}

We first compared the chemiluminescence response, phagocytic uptake, and surface $\mathrm{IgG}$ and $\mathrm{C}_{3}$ immunofluorescence seen with (1) unopsonised organisms, and (2) with organisms opsonised with (a) pooled normal human serum, (b) serum from patients from whom $C$. pylori had been cultured, and (c) serum from patients who were culture negative (fig. 1). With unopsonised organisms there was very little phagocytic uptake and no surface IgG or $\mathrm{C}_{3}$ immunofluorescence detectable. In the presence of opsonising serum, high values were obtained for all four parameters. All sera tested gave similar results. In particular, there was no significant difference between the opsonic activity of serum from patients who were culture positive and those who were culture negative for $C$. pylori.

We also tested ten $C$. pylori isolates against ten different sera but found no significant variation in either opsonic or binding activity.

C. pylori isolated from different sites in the upper gastrointestinal tract were opsonised with serum. 

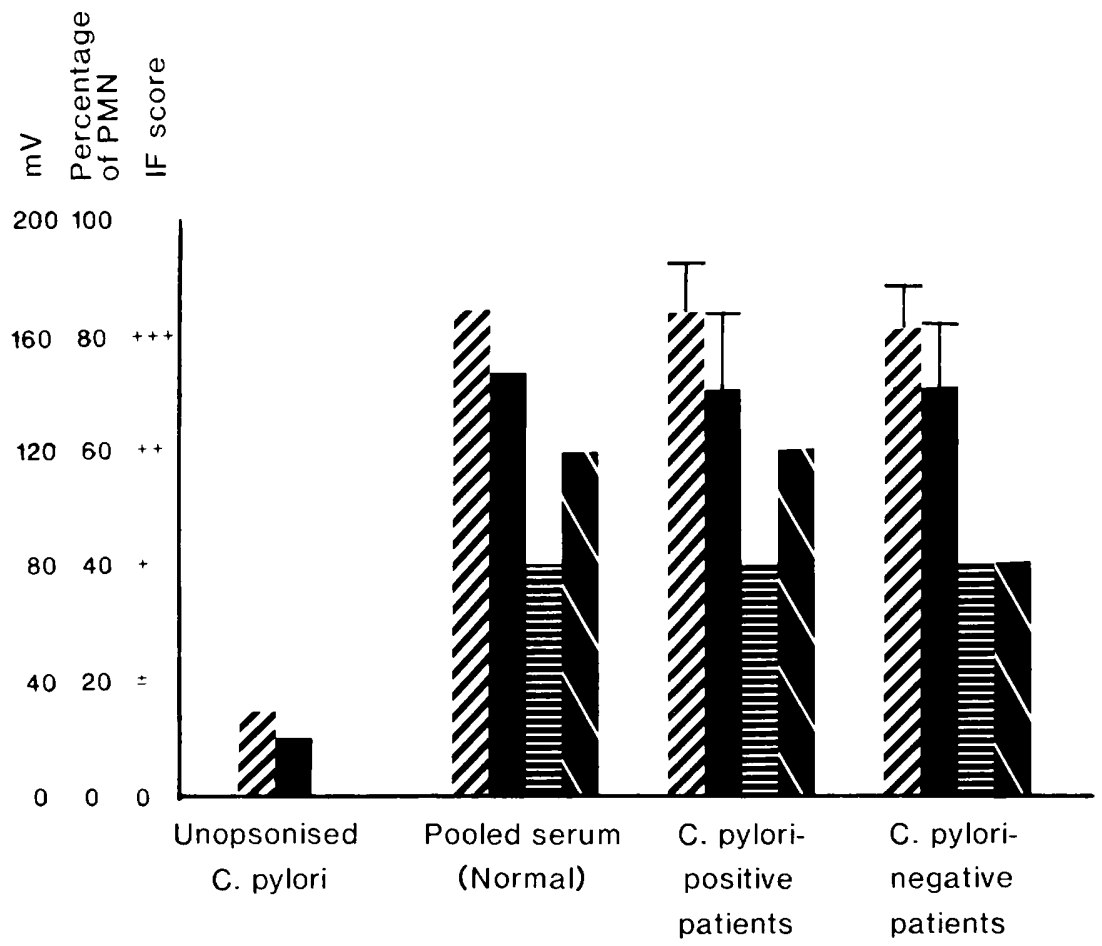

Fig. 1. Opsonic activity against $C$. pylori of pooled normal human serum and of serum from each of 20 . pylori culture positive and 15 culture negative patients measured by: $\square$ chemiluminescence $(\mathrm{mV})$; percentage number of PMN with ingested organisms; 룹 IgG immunofluorescence (IF); $\mathbf{\nabla} \mathrm{C}_{3}$ immunofluorescence (IF). Values expressed as mean for each population group. Bars represent 1 SD. No significant difference $(p>0 \cdot 05)$ was found between culture positive and cultli.e negative patients with respect to opsonophagocytosis determined by: chemiluminescence and microscopical phagocytic assay (t test); and IgG and $\mathrm{C}_{3}$ immunofluorescence (Man-Whitney U test).

Experiments were performed in duplicate for each patient. The average value obtained was used to calculate the mean (with 1 SD shown in brackets), for each site of isolation of $C$. pylori (table). No significant difference $(\mathrm{p}>0.05$, analysis of variance) was seen in opsonophagocytosis of $C$. pylori, measured by chemiluminescence and microscopic phagocytic assay, with respect to the site of isolation of the organism in the upper gastrointestinal tract.

The main serum opsonins are $\mathrm{IgG}, \mathrm{IgM}$ and $\mathrm{C}_{3} \mathrm{~b}$. Serum from an agammaglobulinaemic patient opsonised $C$. pylori as well as did normal human serum despite total lack of IgG binding (fig. 2). In contrast, heat-inactivated serum was a poor opsonin. However, its activity could be restored with fresh agammaglobulinaemic serum, thus demonstrating the importance of complement in opsonophagocytosis of $C$. pylori. Opsonisation occurred in the presence of MgEGTA indicating that the alternative pathway of complement activation alone was sufficient to mediate this effect (fig. 3).

We found that absorption of serum with C.pylori did not affect its opsonic activity although it did eliminate surface IgG immunofluorescence (fig. 3). This, coupled with the data obtained with agammaglobulinaemic serum, indicated no role for antibody.

Table. Effect of site of isolation on opsonophagocytosis of C.pylori*

\begin{tabular}{|c|c|c|c|}
\hline $\begin{array}{l}\text { Site of } \\
\text { isolation }\end{array}$ & $\begin{array}{l}\text { Number of } \\
\text { patients } \\
\text { studied }\end{array}$ & $\begin{array}{l}\text { Chemilum- } \\
\text { inescence value } \\
\text { (SD) in } \mathrm{mV}\end{array}$ & $\begin{array}{c}\text { Percentage } \\
\text { number (SD) } \\
\text { of PMN with } \\
\text { ingested } \\
\text { organisms }\end{array}$ \\
\hline Gastric antrum & 14 & $173(16)$ & $76(8)$ \\
\hline Duodenum & 6 & $168(19)$ & $76(8)$ \\
\hline Oesophagus & 4 & $174(20)$ & $78(10)$ \\
\hline
\end{tabular}

* Experiments were done in duplicate for each patient; average values (SD) are given for each site of isolation (see text). 

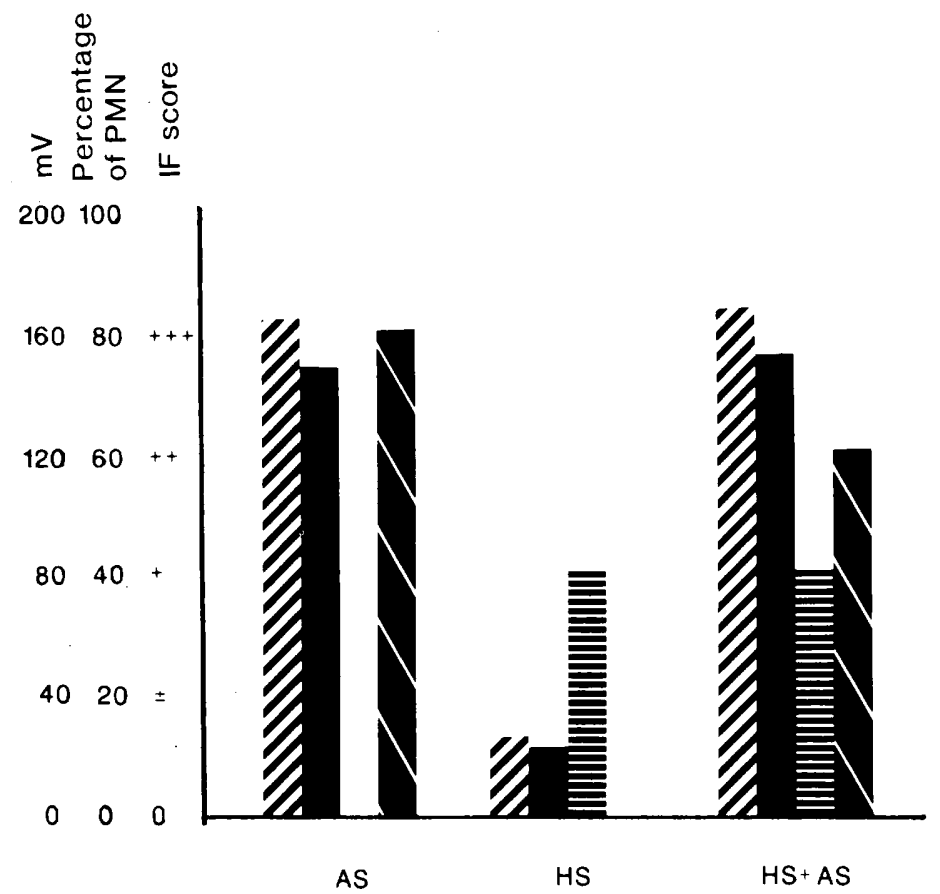

Fig. 2. Opsonic activity against $C$. pylori of agammaglobulinaemic serum (AS), heat-inactivated serum (HS), and of HS + AS,

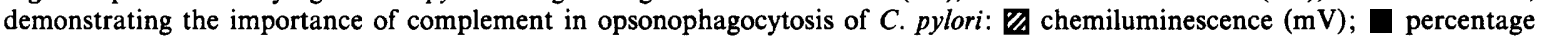
number of PMN with ingested organisms; 目 IgG immunofluorescence (IF); $\mathbb{\nabla} \mathrm{C}_{3}$ immunofluorescence (IF).

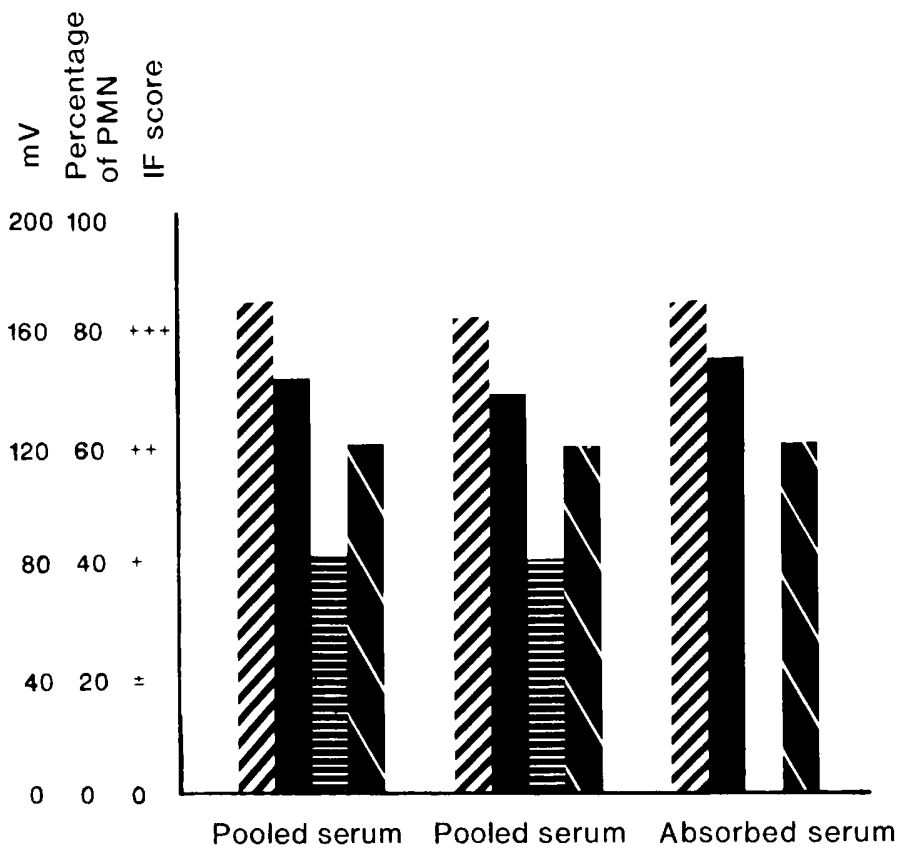

+ MgEGTA

Fig. 3. Opsonic activity of sera chelated with MgEGTA and of absorbed sera against $C$. pylori; $\square$ chemiluminescence (mV); percentage number of PMN with ingested organisms; 目 IgG immunofluorescence (IF); $\triangle \mathrm{C}_{3}$ immunofluorescence (IF). 
In each case, results were the same whether pooled normal human serum or serum from campylobacter culture-positive or culture-negative symptomatic patients was used.

\section{Discussion}

The significance of $C$. pylori in the aetiology of gastritis, duodenitis, and peptic ulcer remains uncertain. The main controversy centres on whether the demonstration of $C$. pylori in mucosal biopsy specimens in these diseases represents a true pathological process or merely reflects colonisation by an organism taking advantage of conditions that favour its growth and multiplication. Findings that support a causal association include: strong correlation with histologically confirmed inflammation; eradication of the organism with specific antimicrobial therapy, correlating with histological, endoscopic and clinical improvement (Langenberg et al., 1985; McNulty et al., 1986); fulfilment of Koch's postulates at least in one case (Marshall et al., 1985); and the demonstration of both a systemic and a local immune response to the organism. Elevated and specific antibody production is often a hallmark of a host response to a microbial pathogen in many infections. Opsonisation is one of the main protective functions of antibody. Complement may be required for optimal opsonic activity.

The aim of our study was to demonstrate whether the serum antibodies against $C$. pylori are opsonic for the organism. Our results indicate that human serum has strong opsonic activity for C. pylori, irrespective of overt infection with the organism. The opsonic activity depended on the alternative pathway of complement activation. Components of the cell wall, such as lipopolysaccharide, of gramnegative bacteria are known to be powerful activators of the alternative complement pathway. During this activation many potent bioactive and chemotactic substances are released. These may be responsible for the underlying intense inflammation seen in mucosal biopsy specimens positive for $C$. pylori. However, even if this is the true mechanism, it clearly fails to eradicate the organism.

Various methods, including complement fixation tests, passive haemagglutination, and ELISA, have been used to detect $C$. pylori-specific antibodies in serum. The prevalence of these antibodies is highest in patients with both organisms and histologically confirmed gastritis and peptic ulcer in biopsy specimens (Jones et al., 1984). Antibodies to $C$. pylori are also detectable in "normal" healthy individuals. In a recent survey (Jones et al., 1986),
$12 \%$ of a random sample of the population aged $21-$ 30 years had antibody to $C$. pylori in their serum. The prevalence of antibody increased with age.

We found that serum antibodies were not important for opsonophagocytosis of $C$. pylori. They are unlikely to be protective in infection caused by this organism. This may help to explain why colonisation with $C$. pylori tends to be a persistent problem, and why relapse of infection is common even after apparent successful eradication of the organism with specific antimicrobial therapy (Tytgat et al., 1986). A possible reason for the lack of opsonic activity of serum antibodies against $C$. pylori is that the antigenic determinants which may stimulate a protective immune response in the host may be located deep inside the cell wall of the bacterium and thus may be inaccessible to host antibodies.

The presence of $C$. pylori has been documented in the gastric mucosa, duodenum (Phillips et al., 1984; Coelho et al., 1987), and the oesophagus (L.G.V. Coelho et al., unpublished observations). Our results indicate that the site of isolation of the organism does not appear to be important in determining opsonophagocytosis in vitro. Testing serum from culture-positive patients, individually, against the homologous and heterologous $C$. pylori isolates showed no difference in opsonophagocytosis. These observations are consistent with the finding that opsonophagocytosis of $C$. pylori is complement-dependent, but not antibody-dependent.

C. pylori-specific IgA, together with low levels of IgM, has been demonstrated in a proportion of patients with gastritis (Rathbone et al., 1986). Immunoperoxidase studies have shown IgG-, IgA-, and IgM-coated C.pylori in tissue sections (Wyatt et al., 1986). Organisms deep within the gastric pits appeared to be uncoated, suggesting that they may be protected in this site from host antibody. We have not examined the effect of $\operatorname{IgA}$. This class of antibody does not function as an opsonin and may even inhibit the opsonic activity of IgG and IgM antibodies. If IgA has any role in defence against C. pylori this is likely to be linked to its effects on bacterial adherence. In contrast to our results Pruul et al. (1987) found that phagocytic killing of $C$. pylori required both specific antibody and an intact complement pathway. The methods used to examine opsonophagocytosis in the two studies were different. We used functional assays to measure phagocytic uptake of bacteria, whereas Pruul et al. employed a bactericidal assay. However, a bacterium may be ingested by a phagocytic cell but not killed. Growth and viability of bacteria in serum 
may also be affected by mechanisms other than opsonophagocytosis, e.g., serum lysis and agglutination. Thus, the results of the two studies cannot be compared directly.

Although we did not find antibodies to be necessary for opsonophagocytosis, the demonstration of $C$. pylori-specific antibodies is of diagnostic importance and is being used to study the epide-

\section{REFERENCES}

Coelho L G V et al. 1987 Campylobacter pylori in the upper gastrointestinal tract: a Brazilian study. Arquivos de Gastroenterologica 24: 5-9.

Jones D M, Lessells A M, Eldridge J 1984 Campylobacter-like organisms of the gastric mucosa: culture, histological, and serological studies. Journal of Clinical Pathology 37: 10021006.

Jones D M, Eldridge J, Fox A J, Sethi P, Whorwell P J 1986 Antibody to the gastric Campylobacter-like organism (Campylobacter pyloridis) - clinical correlations and distribution in the normal population. Journal of Medical Microbiology 22: 57-62.

Kaldor J, Tee W, McCarthy P, Watson J, Dwyer B 1985 Immune response to Campylobacter pyloridis in patients with peptic ulceration. Lancet 1: 921.

Langenberg M L, Rauws E J, Schipper M E I 1985 The pathogenic role of Campylobacter pyloridis studied by attempts to eliminate these organisms. In: Pearson A D et al. (eds) Campylcbacter III: Proceedings of the Third International Workshop of Campylobacter infection. PHLS, London, pp 162-163.

McNulty C A M, Watson D M 1984 Spiral bacteria of the gastric antrum. Lancet 1 : $1068-1069$.

McNulty C A M et al. 1986 Campylobacter pyloridis and associated gastritis: investigator blind, placebo controlled trial of bismuth salicylate and erythromicin ethylsuccinate. British Medical Journal 293: 645-649.

Marshall B 1983 Unidentified curved bacilli on gastric epithelium in active chronic gastritis. Lancet 1: 1273-1275. miology of C. pylori infection (Morris et al., 1986). It may also be useful in monitoring responses to specific antimicrobial therapy directed against $C$. pylori.

We thank Dr J. H. Baron for permission to study patients under his care, Dr A. C. Maddocks for her valuable discussions, and the staff of the Pharmacy department at Dulwich Hospital for help in preparing the manuscript.

Marshall B J, Armstrong J A, McGechie D B, Glancy R J 1985 Attempt to fulfill Koch's postulates for pyloric Campylobacter. Medical Journal of Australia 142: 436-439.

Morris A, Nicholson G, Lloyd G, Haines D, Rogers A, Taylor D 1986 Seroepidemiology of Campylobacter pyloridis. New Zealand Medical Journal 99: 657-659.

Phillips A D, Hine K R, Holmes G K, Woodings D F 1984 Gastric spiral bacteria. Lancet 2: 100-101.

Price A B et al. 1985 Campylobacter pyloridis in peptic ulcer disease: microbiology, pathology and scanning electron microscopy. Gut 26: 1183-1188.

Pruul H, Lee P C, Goodwin C S, McDonald P J 1987 Interaction of Campylobacter pyloridis with human immune defence mechanisms. Journal of Medical Microbiology 23: 233-238.

Rathbone B J et al. 1986 Systemic and local antibody responses to gastric Campylobacter pyloridis in non-ulcer dyspepsia. Gut 27: 642-647.

Stevens P, Winston D J, van Dyke K 1978 In vitro evaluation of opsonic and cellular granulocyte function by luminoldependent chemiluminescence: utility in patients with severe neutropenia and cellular deficiency states. Infection and Immunity 22 : 41-51.

Tytgat G N J, Rauws E A J, Langenberg M L, Hauthoff H J 1986 Campylobacter pyloridis: the Amsterdam study. Digestive Diseases and Sciences 31 : (10) Suppl: 149S, Abstract no. 585.

Wyatt J I, Rathbone B J, Heatley R V 1986 Local immune response to gastric Campylobacter in non-ulcer dyspepsia. Journal of Clinical Pathology 39: 863-870. 